\title{
A CALCIUM/CALMODULIN-DEPENDENT PROTEIN KINASE FROM MAMMALIAN BRAIN THAT PHOSPHORYLATES SYNAPSIN I: PARTIAL PURIFICATION AND CHARACTERIZATION ${ }^{1}$
}

\author{
MARY B. KENNEDY,, 2 TERESA McGUINNESS, $\ddagger$ AND PAUL GREENGARD $\ddagger$ \\ ${ }^{*}$ Division of Biology 216-76, California Institute of Technology, Pasadena, California 91125 and $\$$ Department of \\ Pharmacology, Yale University School of Medicine, New Haven, Connecticut 06510
}

Received August 11, 1982; Revised October 28, 1982; Accepted November 10, 1982

\begin{abstract}
A calcium/calmodulin-dependent protein kinase, which phosphorylates a synaplic vesicle-associated protein designated Synapsin I, has been shown to be present in both soluble and particulate fractions of rat brain homogenates. In the present study, the particulate activity was solubilized by washing with a low ionic strength solution, and the enzymes from the two fractions were partially purified by ion exchange chromatography and calmodulin-Sepharose affinity chromatography. By each of several criteria, the partially purified enzymes from the two sources were indistinguishable. These criteria included specificity for various substrate proteins, concentration dependence of activation by calcium and calmodulin, $\mathrm{pH}$ dependence, and apparent affinities for the substrates Synapsin I and ATP. The mild conditions that released the particulate enzyme indicated that it was not tightly bound to the membrane and suggested that it may exist in a dynamic equilibrium between soluble and particulate-bound states.

The partially purified enzyme preparations from both the soluble and particulate fractions contained three proteins that were phosphorylated in the presence of calcium and calmodulin, a 50kilodalton $(\mathrm{Kd})$ protein and two proteins in the 60-Kd region. When compared by phosphopeptide mapping and two-dimensional gel electrophoresis, the proteins were indistinguishable from three proteins of corresponding molecular weights that were shown by Schulman and Greengard (Schulman, H., and P. Greengard (1978) Nature 271: 478-479) to be prominent substrates for calcium/ calmodulin-dependent protein kinase in a crude particulate preparation from rat brain. The $50-\mathrm{Kd}$ substrate was the major Coomassie blue staining protein in both partially purified enzyme preparations. The peak of this protein coincided with that of enzyme activity during DEAE-cellulose and calmodulin-Sepharose chromatography. These results suggest that the 50-Kd phosphoprotein may be an autophosphorylatable subunit of the Synapsin I Kinase or may exist in a complex with it.
\end{abstract}

Changes in calcium ion concentration play a role in the intracellular control of a number of diverse hiological processes (Kretsinger, 1979). In some cases, such as muscle contraction (Cold Spring Harbor Laboratories, 1972), the mechanism by which calcium ion exerts its effects is fairly well understood. In others, such as the control of synaptic transmission (Kelly et al., 1979) or neuronal gene expression (Walicke and Patterson, 1981), the con-

\footnotetext{
'This work was supported by National Institutes of Health Grants MH-17387 and NS-08440, and a grant from the McKnight Foundation (P. G.); National Institutes of Health Grant NS-17660, the Church Fund, the Muscular Dystrophy Association, the Pew Fund, and the Sloan Fund (M. K.). We wish to thank Dr. Claude Klee for her gift of calmodulin-Sepharose, Barbara Moore for technical assistance, and Candace Hochenedel and Annette Gwardyak for help with preparation of the manuscript.

${ }^{2}$ To whom correspondence should be addressed.
}

trol mechanisms are not clear. In order to understand the molecular mechanisms by which calcium acts, it is necessary to determine the cellular proteins that are regulated by physiological changes in calcium concentration. Recent reports have shown that calcium ion, acting through the small calcium-binding protein, calmodulin, can activate a number of different enzymes (see Cheung, 1980, for review), including protein kinases. Several different calmodulin-dependent protein kinases have been described to date. Three of these-myosin light chain kinase, phosphorylase kinase, and a glycogen synthase kinase-have been purified and are clearly distinct from one another (Dabrowska et al., 1978; Waisman et al., 1978; Yagi et al., 1978; Cohen et al., 1978; Payne and Soderling, 1980; Ahmad et al., 1982).

Several calcium/calmodulin-dependent kinase activities have been observed in relatively crude brain homog- 
enates but have not yet been completely characterized (Schulman and Greengard, 1978a, b; DeLorenzo, et al., 1979; Yamauchi and Fujisawa, 1980; Burke and DeLorenzo, 1981; Grab et al., 1981; Kennedy and Greengard, 1981). The relationship of these various protein kinases to each other and to other calcium/calmodulin-dependent protein kinases is unclear. Thus, the total number of individual calcium/calmodulin-dependent kinases is not yet known. Information about the properties and distributions of each of the neuronal kinases will be necessary for a complete description, at the molecular level, of the responses of various neurons, and of individual synaptic terminals, to changes in calcium flux.

We have previously described two calcium/calmodulin-dependent protein kinase activities in rat brain homogenates (Kennedy and Greengard, 1981). The two kinase activities, which phosphorylate a synaptic vesicleassociated protein designated Synapsin I (previously referred to as Protein I, see Ueda and Greengard, 1977; Ueda et al., 1979; P. De Camilli, S. M. Harris, W. B. Huttner, and P. Greengard, manuscript in preparation), are considerably more concentrated in brain than in other tissues. They were distinguished from each other by their specificity for different sites on the Synapsin I molecule and were also shown to be distinct from myosin light chain kinase and phosphorylase kinase (Kennedy and Greengard, 1981). One of these Synapsin I kinase activities, the " $30 \mathrm{~K}$ region Synapsin I kinase" activity, is present in both the soluble and particulate fractions of brain homogenates. It phosphorylates a pair of serine residues contained in a 30,000-dalton peptide recovered after digestion of Synapsin I with Staphylococcus aureus V8 protease (Kennedy and Greengard, 1981; Huttner et al., 1981). In the present study, we have partially purified and characterized both the soluble and the particulate $30 \mathrm{~K}$ region kinase activities. We report two principal findings. One is that the enzyme activities from the two sources are indistinguishable by several criteria. The second is that both enzyme preparations contain three proteins that are phosphorylated in the presence of calcium and calmodulin and appear to be identical to threc prominent substrate proteins for calcium/calmodulin-dependent protein kinase that were observed in a crude synaptosomal particulate fraction by Schulman and Greengard (1978a, 1978b). One of these, a 50-Kd (kilodalton) protein, is the major protein in both enzyme preparations and co-migrates with enzyme activity during the purification steps.

\section{Materials and Methods}

Materials. ATP, dithioerythritol (DTE), ethylene glycol bis( $\beta$-aminoethyl ether)- $N, N^{\prime}$-tetra-acetic acid (EGTA), 'I'ris, imidazole, phenylmethylsulfonyl fluoride (PMSF), trypsin, casein, phosvitin, gelatin, phosphorylase $\mathrm{b}$, histone IIA, histone IV, bovine serum albumin, ovalbumin, carbonic anhydrase, myoglobin, and cytochrome $c$ were purchased from Sigma. Chymotrypsinogen and chymotrypsin were purchased from Worthington. Microtubule protein was prepared from rat brain by the method of Shelanski et al. (1973). Histone f3 was a gift of Dr. Louis J. DeGennaro. Whole myosin light chain fraction from rabbit skeletal muscle was a gift of Dr. Angus C. Nairn. Cellulose plates were purchased from
Eastman. DEAE-cellulose (DE-52) was purchased from Whatman. Trifluoperazine was purchased from Smith, Kline and French. Ampholines were purchased from LKB. S. aureus V8 protease was purchased from Miles Laboratories. Calmodulin-Sepharose was a gift of Dr. Claude Klee or was prepared by the method of March et al. (1974). $\left[\gamma^{3{ }^{32}} \mathrm{P}\right] \mathrm{ATP}\left(5\right.$ to $\left.10 \times 10^{7} \mathrm{cpm} / \mathrm{nmol}\right)$ was prepared by the method of Glynn and Chappell (1964) from ATP and $\left[{ }^{332} \mathrm{P}\right]$ phosphate (New England Nuclear). The specific activity was adjusted with unlabeled ATP. Calmodulin was prepared from bovine brain by the method of Watterson et al. (1976). Synapsin I was prepared from bovine brain by a modification of the procedure of Ueda and Greengard (1977).

Assays for calcium/calmodulin-dependent Synapsin I kinase activity. Calcium/calmodulin-dependent Synapsin I kinase was assayed, with minor modifications, as previously described (Kennedy and Greengard, 1981) at $30^{\circ} \mathrm{C}$ in a reaction mixture (final volume $100 \mu \mathrm{l}$ ) containing $50 \mathrm{~mm}$ Tris ( $\mathrm{pH} 7.5), 10 \mathrm{~mm} \mathrm{MgCl} 2,5 \mathrm{~mm}$ 2-mercaptoethanol, $1 \mu \mathrm{g}$ of calmodulin, $10 \mu \mathrm{g}$ of Synapsin I, $50 \mu \mathrm{M}$ [ $\left.\gamma^{3}{ }^{32} \mathrm{P}\right]$ ATP $\left(0.5\right.$ to $\left.2 \times 10^{3} \mathrm{cpm} / \mathrm{pmol}\right)$, either $0.4 \mathrm{~mm}$ EGTA (minus calcium) or $0.4 \mathrm{~mm}$ EGTA/0.7 $\mathrm{mm} \mathrm{CaCl}_{2}$ (plus calcium), and varying amounts of soluble or particulate enzyme. After pre-incubation for $1 \mathrm{~min}$, the reaction was initiated by the addition of $\left[\gamma^{-32} \mathrm{P}\right] \mathrm{ATP}$ and terminated after 15 to $30 \mathrm{sec}$, which ensured measurement of initial rates. Incorporation of ${ }^{32} \mathrm{P}$ into Synapsin I was measured by one of two methods. In the crude tissue fractions, incorporation was measured by a "gel method." In this case, the reaction was terminated by addition of $50 \mu \mathrm{l}$ of a "stop solution" containing 9\% SDS, 6\% (v/v) 2mercaptoethanol, $15 \%(\mathrm{w} / \mathrm{v})$ glycerol, $0.186 \mathrm{~m}$ Tris- $\mathrm{HCl}$ $(\mathrm{pH} 6.7)$, and a trace of bromphenol blue. The solution was then boiled for $2 \mathrm{~min}$. Seventy-five microliters of the Synapsin I kinase reaction mixture was subjected to SDS/polyacrylamide gel electrophoresis as previously described (Ueda and Greengard, 1977), except that the final concentration of acrylamide/bis-acrylamide in the stacking gel $(2.5 \mathrm{~cm} \times 16 \mathrm{~cm} \times 1.5 \mathrm{~mm})$ was $3.42 \% / 0.09 \%$ and the final concentration of acrylamide/bis-acrylamide in the separating gel $(14 \mathrm{~cm} \times 16 \mathrm{~cm} \times 1.5 \mathrm{~mm})$ was $8 \%$ / $0.21 \%$. The labeled Synapsin I band was localized by autoradiography, cut out of the dried gel, and placed in liquid scintillation fluid. The radioactivity was quantitated by liquid scintillation spectrometry. Phosphorylation by the calcium-dependent Synapsin I kinase was measured as the difference between incorporation of ${ }^{32} \mathrm{P}$ into Synapsin I in the absence and presence of calcium.

In the chromatography steps, phosphorylation of Synapsin I in the absence of calcium was minimal and incorporation of ${ }^{32} \mathrm{P}$ into Synapsin I was measured by a "TCA method." In this case, the reaction was terminated by addition of $50 \mu \mathrm{l}$ of a "stop solution" containing $0.3 \mathrm{M}$ EDT $\Lambda$ and $2 \mathrm{mg} / \mathrm{ml}$ of bovine serum albumin (as a carrier), followed immediately by $1 \mathrm{ml}$ of ice-cold $7 \%$ trichloroacetic acid (TCA). After $10 \mathrm{~min}$ at $4^{\circ} \mathrm{C}$, the reaction mixture was centrifuged in a Beckman microfuge B for $2.5 \mathrm{~min}$ and the supernatant was removed by aspiration. The pellet was redissolved in $100 \mu \mathrm{l}$ of $0.1 \mathrm{~N}$ $\mathrm{NaOH}$ and immediately reprecipitated with $1 \mathrm{ml}$ of $7 \%$ TCA. After dissolving the final pellet in $100 \mu \mathrm{l}$ of $0.1 \mathrm{~N}$ $\mathrm{NaOH}, 1 \mathrm{ml}$ of Aquasol (New England Nuclear) was 
added and the radioactivity quantitated by liquid scintillation spectrometry. Phosphorylation of Synapsin I by the calcium/calmodulin-dependent kinase was measured as the difference between incorporation of ${ }^{32} \mathrm{P}$ into TCAinsoluble material in the absence and presence of Synapsin I. In studies characterizing the properties of the partially purified kinases, either the "TCA method" or the "gel method" was used, as indicated. The two methods gave similar results.

Preparation of particulate fraction from lysed $P_{2}$ pellet. The $\mathrm{P}_{2}$ (crude synaptosome) pellet was prepared by a modification of the method of Gray and Whittaker (1962). Cortices were removed from 120- to 150-gm male Sprague Dawley rats and homogenized in $10 \mathrm{vol}$ of $5 \mathrm{~mm}$ Tris, $\mathrm{pH} 7,0.32 \mathrm{~m}$ sucrose, $1 \mathrm{~mm}$ DTE, $0.02 \% \mathrm{Na}$ azide by 12 strokes at $900 \mathrm{rpm}$ in a Teflon/glass homogenizer. Large debris was removed from the suspension by centrifugation at $900 \times g$ for $15 \mathrm{~min}$. The supernatant was centrifuged at $10,000 \times g$ for $20 \mathrm{~min}$. The resulting $\mathrm{P}_{2}$ pellet was washed once and subjected to hypotonic lysis by addition of $5 \mathrm{~mm}$ Tris ( $\mathrm{pH} \mathrm{7),} 1 \mathrm{~mm}$ DTE, $100 \mu \mathrm{M}$ PMSF to the same volume as the original suspension. After $30 \mathrm{~min}$, particulate matter was sedimented by centrifugation at $170,000 \times g$ for $1 \mathrm{hr}$. The supernatant was removed and the pellet resuspended in $25 \mathrm{~mm}$ Tris, $1 \mathrm{~mm}$ imidazole, $\mathrm{pH} 7.3,1 \mathrm{~mm}$ DTE, $100 \mu \mathrm{M}$ PMSF, 0.02\% $\mathrm{Na}$ azide.

Endogenous phosphorylation. Incorporation of $\left[{ }^{32} \mathrm{P}\right]$ phosphate into endogenous substrate proteins was measured under the conditions used to measure Synapsin I kinase activity except that Synapsin I was omitted from the assay and $\left[\gamma^{32} \mathrm{P}\right] \mathrm{ATP}$ was used at a lower concentration $(2$ to $4 \mu \mathrm{M})$ and higher specific activity $\left(2\right.$ to $3 \times 10^{4}$ $\mathrm{cpm} / \mathrm{pmol}$ ), which increased ${ }^{32} \mathrm{P}$ incorporation into the endogenous substrates. Labeled proteins were separated by SDS/polyacrylamide gel electrophoresis, and ${ }^{32} \mathrm{P}$ incorporation was quantitated as described for the Synapsin I kinase assay, except that the final concentration of acrylamide/bis-acrylamide in the separating gel was $10 \% / 0.27 \%$.

Tryptic fingerprinting. Tryptic fingerprinting of phosphorylated Synapsin I was performed by modification of the procedure of Axelrod (1978). Dried gel pieces containing labeled Synapsin I were washed with three changes of $10 \%$ methanol to remove residual SDS, rinsed with water, and reswollen in $1 \mathrm{ml}$ of $0.1 \mathrm{M}$ ammonium bicarbonate $(\mathrm{pH} 8.0), 1 \mathrm{~mm}$ DTE, a trace amount of phenol red, $50 \mu \mathrm{g}$ of trypsin (Sigma, Type I, twice recrystallized), and $50 \mu \mathrm{g}$ of chymotrypsin (Worthington, CD1) per $\mathrm{ml}$. The gel pieces were allowed to incubate for 24 to $30 \mathrm{hr}$ at $37^{\circ} \mathrm{C}$, after which time the eluate was removed and lyophilized. The residue was dissolved in $30 \mu \mathrm{l}$ of electrophoresis buffer $(10 \%(\mathrm{v} / \mathrm{v})$ acetic acid, $1 \%(\mathrm{v} / \mathrm{v})$ pyridine ( $\mathrm{pH} 3.5)$ ), and a $20-\mu \mathrm{l}$ aliquot was spotted on Eastman chromagram cellulose plates. The samples were electrophoresed for $90 \mathrm{~min}$ at $400 \mathrm{~V}$ in the first dimension, dried, and then subjected to ascending chromatography in $n$-butanol/pyridine/acetic acid/water (37.5:25:7.5:30) in the second dimension. The plates were dried and analyzed by autoradiography.

Two-dimensional gel electrophoresis. Two-dimensional gel electrophoresis (nonequilibrium $\mathrm{pH}$ gradient gel electrophoresis in the first dimension followed by
SDS/polyacrylamide gel electrophoresis in the second dimension) was performed as described by O'Farrell et al. (1977) with minor modifications. The gels to be used for the first dimension were poured to a height of 11.5 $\mathrm{cm}$ in glass tubes (5 mm inside diameter) with the gel mixture containing $2 \%$ Ampholine ( $\mathrm{pH} 3.5$ to 10$)$. The

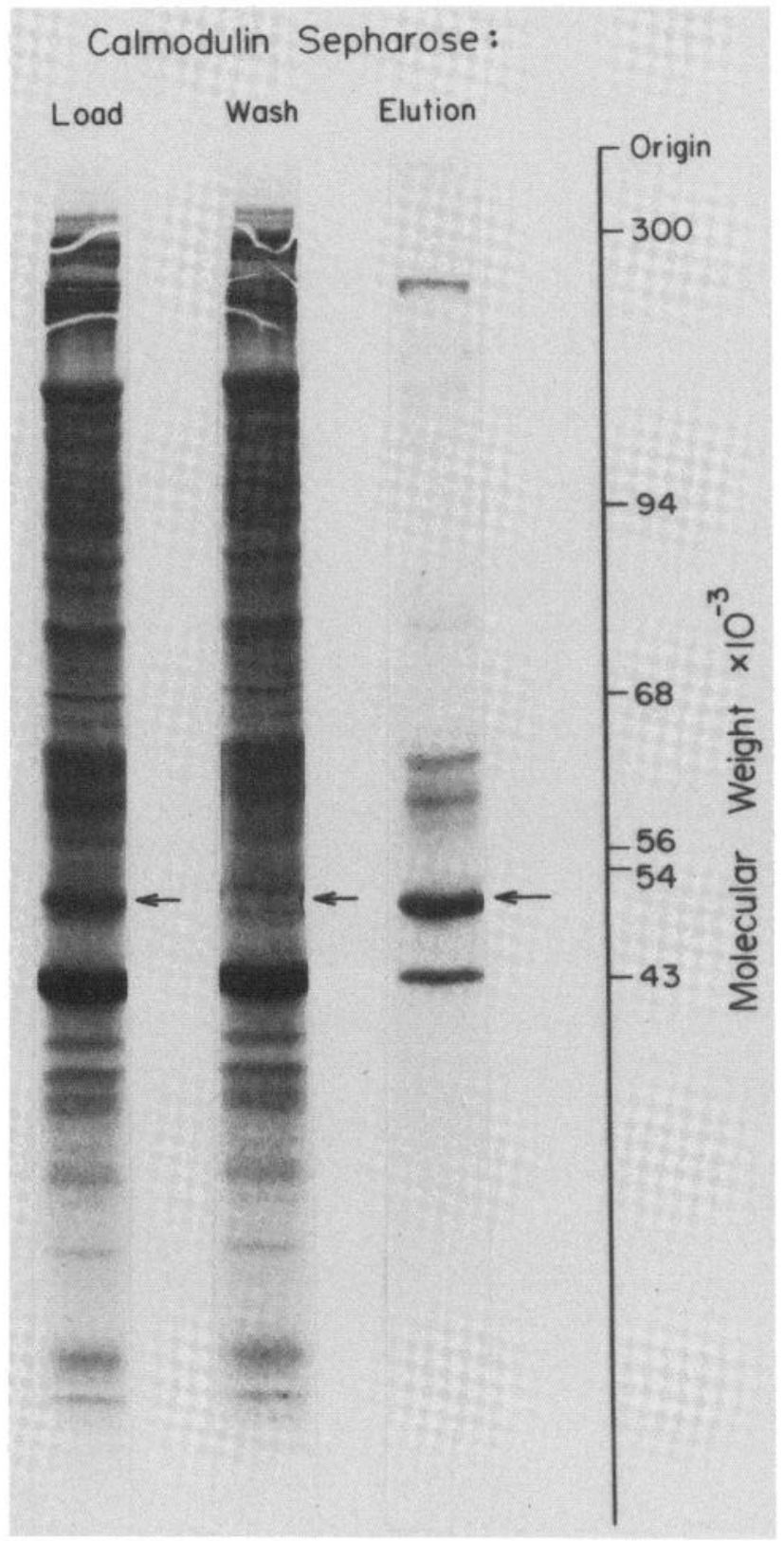

Figure 1. Protein-staining pattern of the soluble Synapsin I kinase preparation before and after purification by calmodulinSepharose affinity chromatography. The preparations were subjected to SDS/polyacrylamide gel electrophoresis on a $10 \%$ gel, followed by staining for protein with Coomassie brilliant blue. Load: $50-\mu \mathrm{g}$ aliquot of the DEAE-cellulose pool (step 4, Table I). Wash: $50-\mu \mathrm{g}$ aliquot of the proteins that did not bind to calmodulin-Sepharose in the presence of calcium. Elution: 5$\mu \mathrm{g}$ aliquot of the proteins that bound to calmodulin-Sepharose in the presence of calcium and were eluted by a solution containing EGTA (step 5, Table I). The arrows mark the position of the 50-Kd protein. The positions of $\alpha$ - and $\beta$-tubulin are marked as 56 and $54 \mathrm{Kd}$, respectively. 
gels were overlayed with water and allowed to polymerize for 2 to $3 \mathrm{hr}$. The sample to be applied was adjusted to the composition of urea lysis buffer $(9.5 \mathrm{~m}$ urea, $10 \%$ sucrose, $1 \%$ Ampholine $(0.8 \% \mathrm{pH} 5$ to $7,0.2 \% \mathrm{pH} 3.5$ to 10 ), $1 \%$ Nonidet P-40, 5\% (v/v) 2-mercaptoethanol). This mixture was layered on top of the gel and overlayed with $40 \mu \mathrm{l}$ of a solution containing $8 \mathrm{~m}$ urea, $1 \%$ Ampholine (pH 3.5 to 10). The gels were electrophoresed for a total of 1,500 to $1,600 \mathrm{~V} \mathrm{hr}$. The gels were removed from the glass tubes and equilibrated with $10 \mathrm{ml}$ of $3 \%$ SDS, $2 \%$ (v/v) 2-mercaptoethanol, $5 \%(\mathrm{w} / \mathrm{v})$ glycerol, 0.062 м Tris$\mathrm{HCl}(\mathrm{pH}$ 6.7), and a trace of bromphenol blue for $2 \mathrm{hr}$. They were then placed on top of an SDS/polyacrylamide slab gel consisting of a 4-cm long stacking gel and a $14-\mathrm{cm}$ long separating gel $(10 \%$ acrylamide $/ 0.27 \%$ bisacrylamide). Electrophoresis was performed as described (Ueda and Greengard, 1977). The slab gels were stained in $50 \%$ methanol, $7 \%$ acetic acid, and $0.005 \%$ Coomassie blue for $36 \mathrm{hr}$ and destained in $7 \%$ acetic acid. The gels were then dried and analyzed by autoradiography. Inclusion of SDS in the applied sample did not help reduce streaking of the proteins of interest in the first dimension.

Other procedures. Peptide mapping of phosphoproteins was performed with $S$. aureus V8 protease by the method of Cleveland et al. (1977), as previously described (Kennedy and Greengard, 1981). Protein determination was performed by a modification of the method of Lowry et al. (1951) using bovine serum albumin as a standard. Molecular weight, standards used in SDS/polyacrylamide gel electrophoreses were: microtubule-associated protein $_{2}, 300 \mathrm{Kd}$; phosphorylase $\mathrm{b}, 94 \mathrm{Kd}$; bovine serum albumin, $68 \mathrm{Kd}$; $\alpha$-tubulin, $56 \mathrm{Kd} ; \beta$-tubulin, $54 \mathrm{Kd}$; ovalbumin, $43 \mathrm{Kd}$; carbonic anhydrase, $29 \mathrm{Kd}$; chymotrypsinogen, $25 \mathrm{Kd}$; myoglobin, $17 \mathrm{Kd}$; and cytochrome c, $11.7 \mathrm{Kd}$.

\section{Results}

Partial purification of the soluble $30 \mathrm{~K}$ region Synapsin I kinase. All purification steps were performed at 0 to $4^{\circ} \mathrm{C}$. Brains ( $1.4 \mathrm{gm}$ each) were removed from twenty 150- to 200 -gm male Sprague Dawley rats and homogenized immediately by 12 up-and-down strokes with a Teflon/glass homogenizer at $1200 \mathrm{rpm}$ in $10 \mathrm{vol}$ of buffer A (20 mM Tris (pH 7.3), $1 \mathrm{~mm}$ imidazole, $1 \mathrm{~mm}$ DTE, 0.1 mм PMSF, $0.1 \mathrm{~mm} \mathrm{CaCl}_{2}$ ) containing $1 \mathrm{~mm}$ magnesium acetate. The PMSF was added from a fresh $0.1 \mathrm{~m}$ solution in dimethylsulfoxide. The homogenate was centrifuged at $10,000 \times g$ for $20 \mathrm{~min}$ to remove large debris and particles. The supernatant was centrifuged at $170,000 \times$ $g$ for $1 \mathrm{hr}$, and the resultant supernatant and pellet were used as the sources of soluble and particulate Synapsin I kinase activities, respectively. The soluble fraction was adjusted to $\mathrm{pH} 7.3$ and applied to a DEAE-cellulose column $(2.5 \times 18 \mathrm{~cm})$ previously equilibrated with buffer A. The column was washed with one column volume of $0.05 \mathrm{M} \mathrm{NaCl}$ in buffer $\mathrm{A}$. The column was then developed with a linear gradient of 0.05 to $0.3 \mathrm{M} \mathrm{NaCl}$ in buffer $\mathrm{A}$, as previously described (Kennedy and Greengard, 1981). The fractions containing Synapsin I kinase activity (usually between 0.13 and $0.18 \mathrm{M} \mathrm{NaCl}$ ) were pooled and adjusted to $0.1 \mathrm{~m}$ 'Tris, $\mathrm{pH} 7.3,1 \mathrm{~mm}$ DTE, $0.1 \mathrm{~mm}$ PMSF. Solid ammonium sulfate was added to $70 \%$ saturation.
After 3 to $12 \mathrm{hr}$, precipitated protein was collected by centrifugation, redissolved in a small volume of buffer B (40 mm Tris, pH 7.5, $0.2 \mathrm{~mm} \mathrm{CaCl}_{2}, 1 \mathrm{~mm}$ DTE, $0.1 \mathrm{~mm}$ PMSF) containing $0.2 \mathrm{M} \mathrm{NaCl}$, and applied to a calmodulin-Sepharose affinity column $(1 \times 8 \mathrm{~cm})$ at a flow rate of $8 \mathrm{ml} / \mathrm{hr}$. More than $95 \%$ of the enzyme activity was retained on the column under these conditions. The column was washed for 8 to $12 \mathrm{hr}$ with buffer B containing $2 \mathrm{~m} \mathrm{NaCl}$. Enzyme activity was eluted as a narrow peak with $40 \mathrm{~mm}$ Tris, $p H$ 7.5, $0.2 \mathrm{M} \mathrm{NaCl}, 2 \mathrm{~mm}$ EGTA, $1 \mathrm{~mm}$ DTE, $0.1 \mathrm{~mm}$ PMSF. Recovery of enzyme activity from the column ranged from 30 to $60 \%$. A 20 - to 30 -fold purification was obtained upon calmodulin-Sepharose affinity chromatography. Following these purification steps, greater than $90 \%$ of the radioactive phosphate incorporated into Synapsin I in the presence of the enzyme was recovered in the 30 -Kd proteolytic fragment. Thus, $10 \mathrm{~K}$ region Synapsin I kinase activity was almost completely absent. The protein-staining pattern of the preparation before and after calmodulin-Sepharose chromatography is illustrated in Figure 1. The preparation contained a major band at $50 \mathrm{Kd}$, minor bands at 250 and $43 \mathrm{Kd}$, and several minor bands between 60 and 70 Kd (see also Fig. 10). In order to preserve enzyme activity, the fractions containing activity were pooled and adjusted to a concentration of $0.3 \mathrm{mg} / \mathrm{ml}$ of bovine serum albumin. This preparation is referred to as the "partially

TABLE I

Partial purification of the $30 \mathrm{~K} \cdot$ region Synapsin I kinase from the soluble fraction

\begin{tabular}{|c|c|c|c|c|c|}
\hline Step & $\begin{array}{c}\text { Total } \\
\text { Activity }\end{array}$ & $\begin{array}{l}\text { Total } \\
\text { Protein }\end{array}$ & $\begin{array}{l}\text { Specific } \\
\text { Activity }\end{array}$ & $\begin{array}{l}\text { Purifi- } \\
\text { cation }\end{array}$ & $\begin{array}{l}\text { Recov- } \\
\text { ery }^{a}\end{array}$ \\
\hline & $\mu \mathrm{mol} / \mathrm{min}$ & $m g$ & $\begin{array}{c}\mu m o l / m i n / \\
m g\end{array}$ & -fold & $\%$ \\
\hline 1. Homogenate & 11.5 & 3609 & 0.0032 & 1 & \\
\hline $\begin{array}{l}\text { 2. } 10,000 \times g \text { super- } \\
\text { natant }\end{array}$ & 4.6 & 1026 & 0.0045 & 1.4 & \\
\hline $\begin{array}{l}\text { 3. } 170,000 \times g \text { super- } \\
\text { natant }\end{array}$ & 3.5 & 737 & 0.0047 & 1.5 & 100 \\
\hline 4. DEAE-cellulose & 2.5 & 102 & 0.025 & 7.8 & 70 \\
\hline $\begin{array}{l}\text { 5. Calmodulin-Sepha- } \\
\text { rose }\end{array}$ & 1.1 & 2.3 & 0.480 & 150 & 31 \\
\hline
\end{tabular}

${ }^{n}$ Recovery is expressed as percentage of activity in the $170,000 \times g$ supernatant.

TABLE II

Partial purification of the $30 \mathrm{~K}$ region Synapsin I kinase from the particulate fraction

\begin{tabular}{lccccc}
\hline \multicolumn{1}{c}{ Step } & $\begin{array}{c}\text { Total } \\
\text { Activity }\end{array}$ & $\begin{array}{c}\text { Total } \\
\text { Protein }\end{array}$ & $\begin{array}{c}\text { Specific } \\
\text { Activity }\end{array}$ & $\begin{array}{c}\text { Purifi- } \\
\text { cation }\end{array}$ & $\begin{array}{c}\text { Recov- } \\
\text { ery }^{a}\end{array}$ \\
\hline & $\mu$ mol/min & $m g$ & $\begin{array}{c}\mu m o l / m i n / \\
m g\end{array}$ & - fold & $\%$ \\
1. Homogenate & 11.5 & 3609 & 0.0032 & 1 & \\
2. $\quad \begin{array}{c}\text { 10,000 } \times g \text { super- } \\
\quad \text { natant }\end{array}$ & 4.6 & 1026 & 0.0045 & 1.4 & \\
3. $\quad 170,000 \times g$ pellet & 1.3 & 204 & 0.0064 & 2.0 & 100 \\
3a. $\quad 170,000 \times g$ pellet & 0.93 & 92 & 0.010 & 3.2 & 71 \\
$\quad$ extract & & & & & \\
4. DEAE-cellulose & 0.51 & 15 & 0.034 & 10.6 & 39 \\
5. Calmodulin- & 0.20 & 0.40 & 0.50 & 156 & 15 \\
$\quad$ Sepharose & & & & & \\
\hline
\end{tabular}

${ }^{a}$ Recovery is expressed as percentage of activity in the $170,000 \times g$ pellet. 


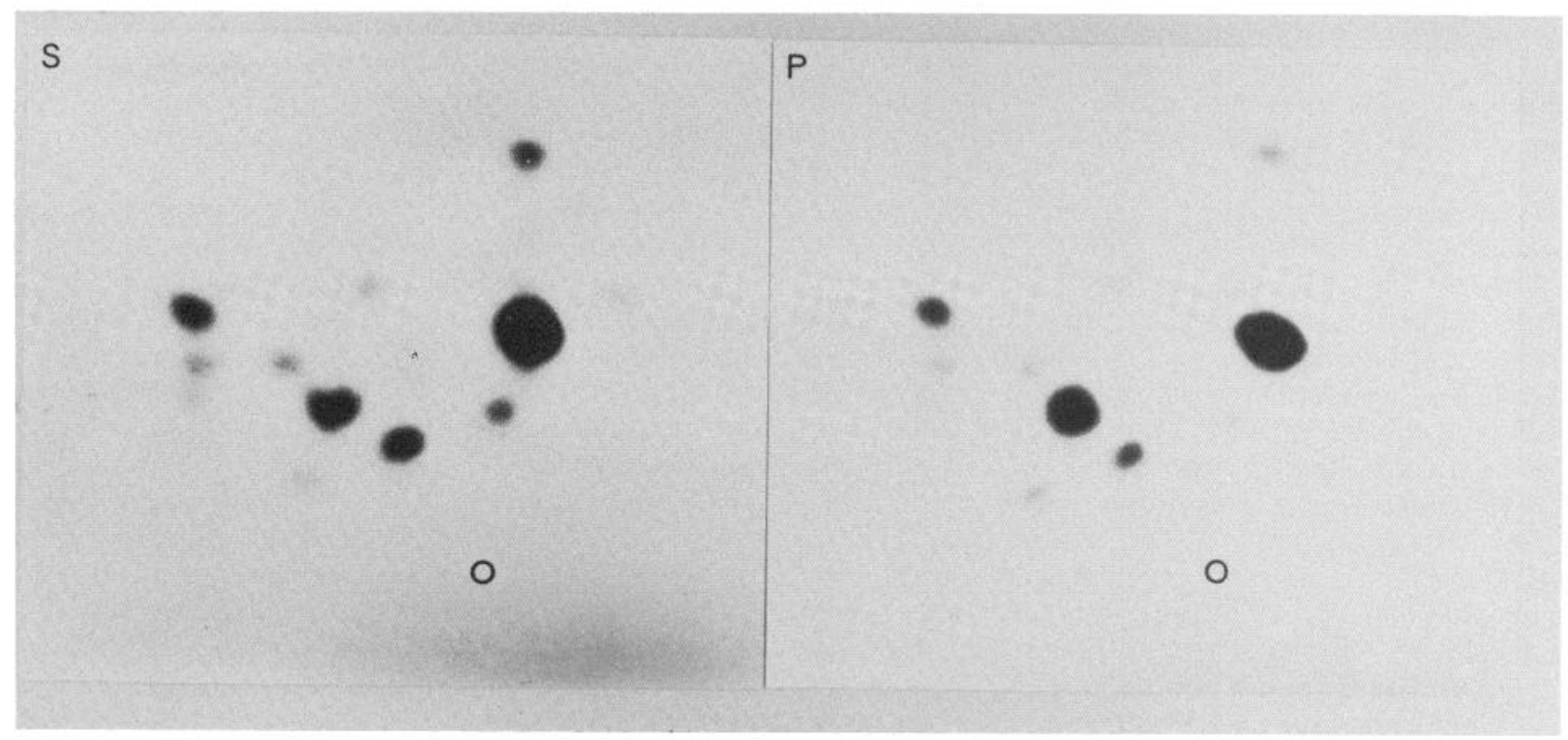

Figure 2. Comparison of the partially purified kinases from the soluble and particulate fractions: autoradiogram showing tryptic fingerprints of phosphorylated bovine Synapsin I. Synapsin I $(5 \mu \mathrm{g})$ phosphorylated by the soluble $(S)$ and particulate $(P)$ kinase preparations was subjected to SDS/polyacrylamide gel electrophoresis. The Synapsin I bands were cut from the gels and subjected to tryptic fingerprinting as described under "Materials and Methods."

TABLE III

Substrate specificities of the partially purified soluble and particulate Synapsin I kinases

The rate of incorporation of phosphate into substrate was determined with the "gel method," using an incubation time of $15 \mathrm{sec}$. The concentrations of the substrates were: Synapsin I, $0.1 \mathrm{mg} / \mathrm{ml}$; histone, $\mathrm{H} 3,0.1 \mathrm{mg} / \mathrm{ml}$; myosin light chains, $0.3 \mathrm{mg} / \mathrm{ml}$; phosphorylase $\mathrm{b}, 0.3$ $\mathrm{mg} / \mathrm{ml}$; casein, $0.4 \mathrm{mg} / \mathrm{ml}$; phosvitin, $0.4 \mathrm{mg} / \mathrm{ml}$; gelatin, $0.2 \mathrm{mg} / \mathrm{ml}$. Histone IV fraction (Sigma) was used as the source of histone H3. The rate of phosphorylation of Synapsin I by the soluble kinase was 64 $\mathrm{pmol} / \mathrm{min}$ and by the particulate kinase was $37 \mathrm{pmol} / \mathrm{min}$. Similar results were obtained in two separate experiments.

\begin{tabular}{lcc}
\hline \multirow{2}{*}{ Substrate } & \multicolumn{2}{c}{ Phosphorylation of Substrate } \\
\cline { 2 - 3 } & Soluble & Particulate \\
\hline Synapsin I & \multicolumn{2}{c}{$\%$} \\
Histone H3 & 14 & 100 \\
Myosin light chains & 2 & 13 \\
Phosphorylase b & 1.4 & 2 \\
Casein & 1.1 & 1.1 \\
Phosvitin & n.d. & 1 \\
Gelatin & n.d. & n.d. \\
\hline
\end{tabular}

${ }^{a}$ n.d., not detectable.

purified soluble kinase." The purification procedure is summarized in Table I.

Solubilization and partial purification of the particulate $30 \mathrm{~K}$ region Synapsin I kinase. In preliminary experiments, solubilization of the particulate enzyme was found to be enhanced both by dilution of the membranes and by reduction of the buffer concentration. Therefore, in our standard procedure, the $170,000 \times g$ pellet was resuspended in $400 \mathrm{ml}$ of $5 \mathrm{~mm}$ piperazine- $N, N^{\prime}$ bis(ethanesulfonic acid) (PIPES), pH 7.3, 1 mM DTE, 0.1 mM PMSF. The suspension was stirred on ice for $2 \mathrm{hr}$, and the particulate fraction was sedimented by centrifugation at $100,000 \times g$ for $1.5 \mathrm{hr}$. About 50 to $70 \%$ of the activity was extracted by this procedure. An additional
10 to $15 \%$ of the original particulate activity could be solubilized by a second extraction of the particulate residue under the same conditions. The extraction by dilute buffer was not due simply to lysis of vesicles, because suspension in low ionic strength isotonic sucrose was equally effective in solubilizing the activity. A number of reagents, including various ionic and nonionic detergents, high ionic strength buffers, divalent cation chelating agents, and chaotropic salts, were also tested for their ability to extract kinase activity from the particulate fraction. None of these treatments were as effective as the dilute low ionic strength buffer in solubilizing the activity. Additionally, high salt concentration or detergents partially inhibited the kinase activity.

The solubilized proteins were loaded onto a DEAE column $(2.5 \times 7 \mathrm{~cm})$ at a flow rate of $60 \mathrm{ml} / \mathrm{hr}$. The column was washed with one column volume of buffer A and developed with a linear gradient of 0 to $0.3 \mathrm{M} \mathrm{NaCl}$ in buffer A. Fractions containing activity (usually 0.13 to $0.17 \mathrm{M} \mathrm{NaCl}$ ) were pooled and adjusted to $0.1 \mathrm{M}$ Tris, $\mathrm{pH}$ 7.3, $1 \mathrm{~mm}$ DTE, 0.1 mM PMSF. When an aliquot of the particulate enzyme activity from the DEAE-cellulose pool was mixed with an equal amount of enzyme activity from the partially purified soluble kinase and rechromatographed on a DEAE-cellulose column $(0.75 \times 6 \mathrm{~cm})$, the activities eluted as a single peak.

The remaining steps in the purification were carried out as described in the previous section for the soluble enzyme. The fractions in the eluate from the calmodulinSepharose column were pooled and adjusted to a concentration of $0.3 \mathrm{mg} / \mathrm{ml}$ of bovine serum albumin (BSA). This preparation is referred to as the "partially purified particulate kinase." Its protein composition was similar to that of the partially purified soluble kinase. The purification procedure is summarized in Table II.

The standard procedure described for the purification of the soluble and particulate activities was carried out 
four times. Both the partially purified soluble enzyme and the partially purified particulate enzyme could be stored on ice in $0.3 \mathrm{mg} / \mathrm{ml}$ of BSA for several weeks with little loss of activity. For long term storage the enzymes were frozen at $-70^{\circ} \mathrm{C}$ in aliquots. Each cycle of freezing and thawing resulted in loss of about $60 \%$ of the enzyme activity. Freezing in $20 \%$ glycerol did not protect against this loss. Attempts to purify the enzymes further have resulted in poor recoveries.

Substrate specificity. Both the soluble and particulate Synapsin I kinases were purified on the basis of their ability to phosphorylate the $30-\mathrm{Kd}$ region of Synapsin I. The site specificity of the two enzymes was examined in more detail by preparing tryptic fingerprints of phosphorylated Synapsin I (Fig. 2). The tryptic maps of bovine Synapsin I phosphorylated by the partially purified soluble and particulate kinases were almost identical. The bovine phosphopeptides differ in their positions and ratios from the previously described rat phosphopeptides (Huttner and Greengard, 1979), reflecting minor species differences in the structure of Synapsin I.

The ability of the two enzyme preparations to phosphorylate a number of additional substrates frequently used for assaying protein kinases was examined. As shown in Table III, apart from Synapsin I, only histone H3 was phosphorylated at a significant rate, under the conditions used. Similar results were obtained for phosphorylation of histone $\mathrm{H} 3$ whether histone IV, histone IIa, or histone $\mathrm{f} 3$ was used as the source of histone $\mathrm{H} 3$. None of the other histone bands in any of the three H3 preparations was phosphorylated. Myosin light chain, phosphorylase $\mathbf{b}$, and casein were found to be weak substrates at the concentrations shown. Some of the proteins might be phosphorylated at higher rates if they were present at a higher concentration. However, the experiment indicates that none of them was phosphorylated as well as Synapsin I at an equivalent concentration. The substrate specificities of the two enzyme preparations were nearly identical.
Kinetic properties. Optimal conditions for catalysis of phosphorylation of Synapsin I were determined for the two enzyme preparations. The $\mathrm{pH}$ dependence (Fig. 3), the calcium requirement (apparent $K_{m}=4 \mu \mathrm{M}$, Fig. 4), and the calmodulin requirement (apparent $K_{m}=0.4 \mu \mathrm{M}$, Fig. $5 A$ ) were virtually identical for the two enzyme

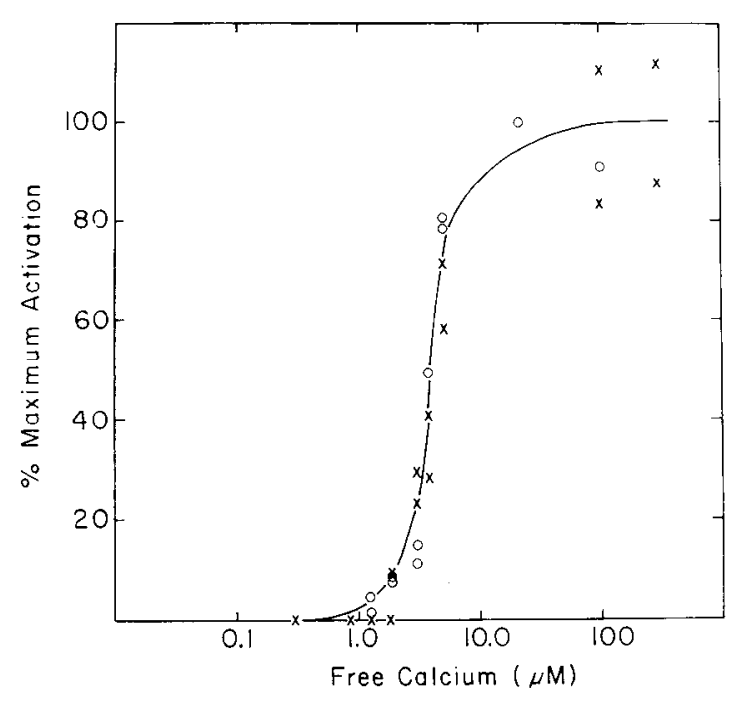

Figure 4. Comparison of the partially purified kinases from the soluble and particulate fractions: calcium dependence. Assays were carried out using an incubation time of $15 \mathrm{sec}$, and phospho-Synapsin I was measured by the "gel method." Free calcium concentration was controlled by use of a $\mathrm{Ca}^{2+} /$ EGTA buffer containing $0.4 \mathrm{~mm}$ EGTA. The assays were carried out at $\mathrm{pH} 6.6$ because, at higher $\mathrm{pH}$ values, EGTA does not adequately buffer free calcium concentrations above $2 \mu \mathrm{M}$. An apparent binding constant of $7.76 \times 10^{5} \mathrm{M}^{-1}$ for $\mathrm{Ca}^{2+} /$ EGTA at this $\mathrm{pH}$ was used to calculate free calcium concentration (Portzehl et al., 1964). Despite the poor calcium-buffering capacity of EGTA at $\mathrm{pH} 7.1$, estimates indicated that the $K_{a}$ for calcium ion was not greatly reduced at this $\mathrm{pH}$. $\mathrm{x}$, soluble kinase; $\mathrm{o}$, particulate kinase.

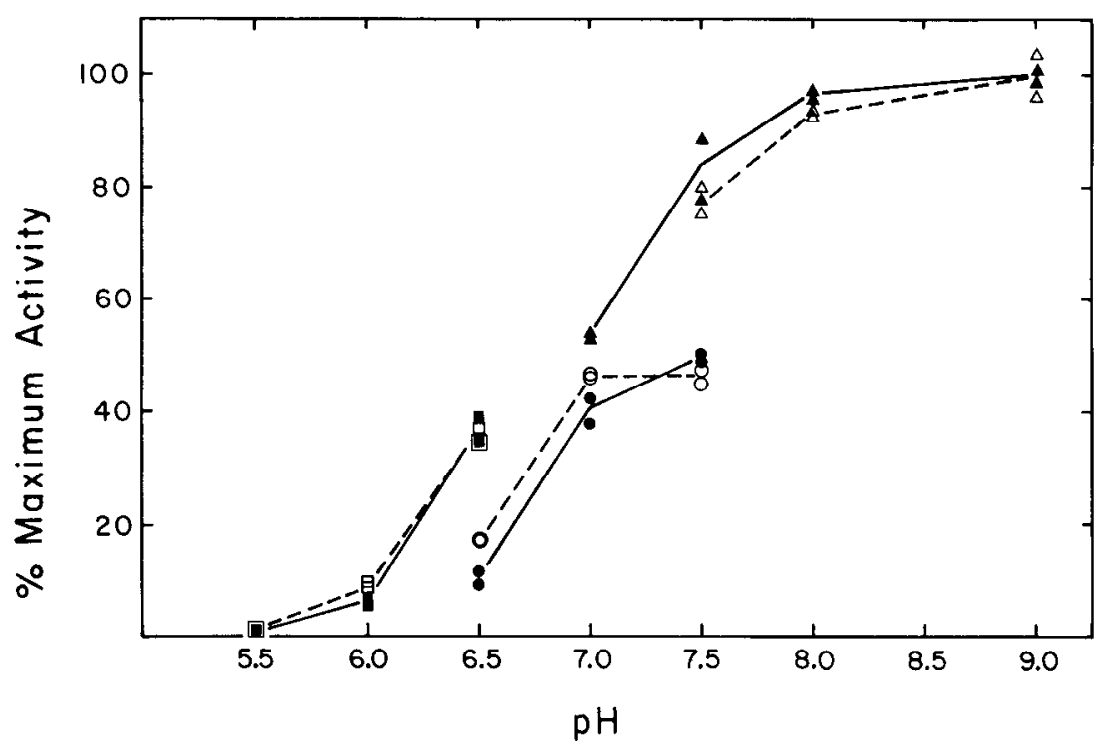

Figure 3. Comparison of the partially purified kinases from the soluble and particulate fractions: $\mathrm{pH}$ dependence. Assays were carried out in duplicate using an incubation time of $15 \mathrm{sec}$, and phospho-Synapsin I was measured by the "TCA method." $\Delta, \triangle$ : $50 \mathrm{~mm}$ Tris-HCl;, , $: 50 \mathrm{~mm}$ PIPES; $\mathbf{\square}, \square: 50 \mathrm{~mm} 2-(N$-morpholino)ethanesulfonic acid; open symbols, soluble kinase; solid symbols, particulate kinase. 

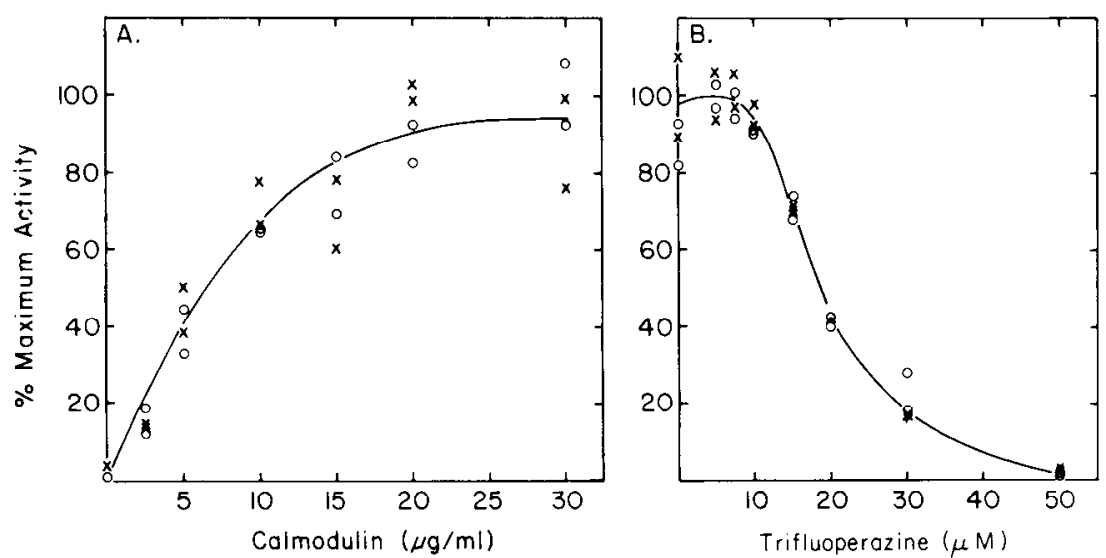

Figure 5. Comparison of the partially purified kinases from the soluble and particulate fractions: activation by calmodulin and inhibition by trifluoperazine. $A$, Assays were carried out in duplicate using an incubation time of 15 sec, and phospho-Synapsin I was measured by the "gel method." The amounts of soluble and particulate kinases used were $0.43 \mu \mathrm{g} /$ assay and $1.3 \mu \mathrm{g} /$ assay, respectively. $B$, Assays were carried out in duplicate using $20 \mu \mathrm{g} / \mathrm{ml}$ of calmodulin and an incubation time of 20 sec. PhosphoSynapsin I was measured by the "gel method." The amounts of soluble and particulate kinases used were $0.29 \mu \mathrm{g} / \mathrm{assay}$ and 0.24 $\mu \mathrm{g} /$ assay, respectively. $\mathrm{x}$, soluble kinase; $\mathrm{o}$, particulate kinase.
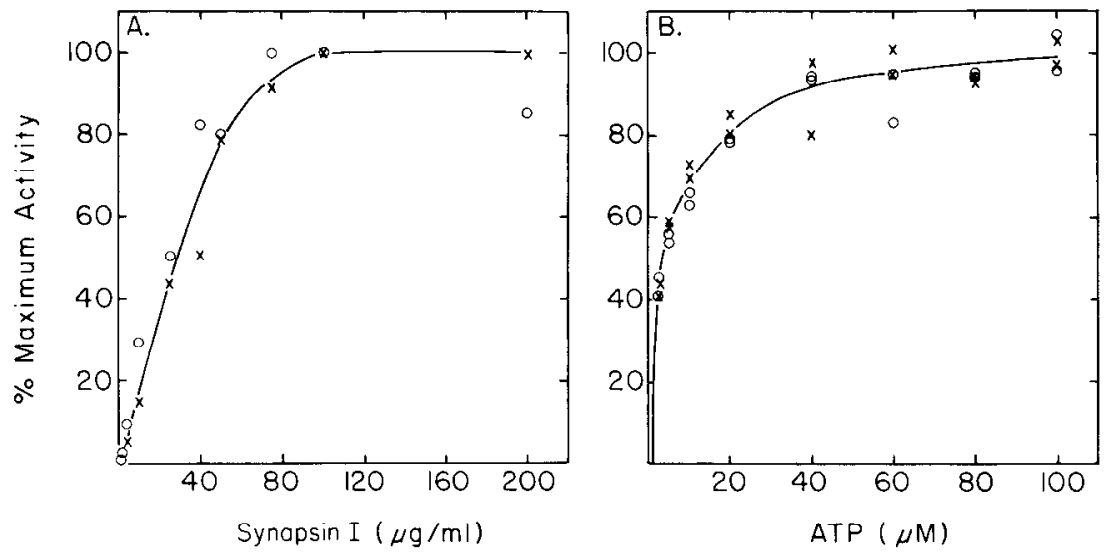

Figure 6. Comparison of the partially purified kinases from the soluble and particulate fractions: dependence on the concentrations of the substrates Synapsin I and ATP. A, Assays were carried out using an incubation time of 15 sec, and phosphoSynapsin I was measured by the "gel method." B, Assays were carried out in duplicate using an incubation time of 20 sec, and phospho-Synapsin I was measured by the "gel method." x, soluble kinase; 0 , particulate kinase.

preparations. (It should be noted that the $K_{m}$ value for calcium in the experiment of Figure 4 is arbitrary because it is dependent on the calmodulin concentration.) Moreover, both preparations of enzyme were inhibited by low concentrations of trifluoperazine, with an $\mathrm{IC}_{50}$ of $18 \mu \mathrm{M}$ under the experimental conditions used (Fig. $5 B$ ). 'The optimal concentrations of the substrates, Synapsin I and ATP, were the same for the two forms (Fig. 6). The dependence of enzyme activity on Synapsin I concentration did not follow Michaelis-Menton kinetics; however, the concentration of Synapsin I required for half-maximal activity was $30 \mu \mathrm{g} / \mathrm{ml}$, or $0.4 \mu \mathrm{M}$, for both kinases. The dependence of enzyme activity on ATP concentration did follow Michaelis-Menton kinetics; analysis of the data by the method of Eadie (1942) and Hofstee (1959), using the least squares method to fit the line, gave a $K_{m}$ for ATP of $3.0 \mu \mathrm{M}$ for the soluble kinase and $3.9 \mu \mathrm{M}$ for the particulate kinase.

Presence of substrate proteins in the partially purified enzyme preparations. In an earlier study of endogenous calcium/calmodulin-dependent protein phosphorylation in a crude synaptosomal membrane fraction from brain, it was found that the phosphorylation of several proteins, including a prominent single band at $50 \mathrm{Kd}$ and a doublet at about $60 \mathrm{Kd}(58 \mathrm{Kd}$ and $61 \mathrm{Kd}$ ), was stimulated by calcium plus calmodulin (Schulman and Greengard, 1978a). The phosphorylation of three proteins with the same molecular weights was stimulated by calcium plus calmodulin in crude particulate fractions prepared from brain homogenates (Schulman and Greengard, 1978b; Fig. 7). We have found that three substrate proteins of molecular weights 50,58 , and $61 \mathrm{Kd}$ were also present in the partially purified enzyme preparations from both the soluble and particulate fractions (Fig. 7). The endogenous substrate proteins present in the partially purified Synapsin I kinase preparations were compared with those in the crude particulate fraction by two-dimensional gel electrophoresis. It can be seen in Figure 8 that the three substrates present in the partially purified soluble kinase preparation and the 50-, 58-, and 61-Kd substrates pres- 


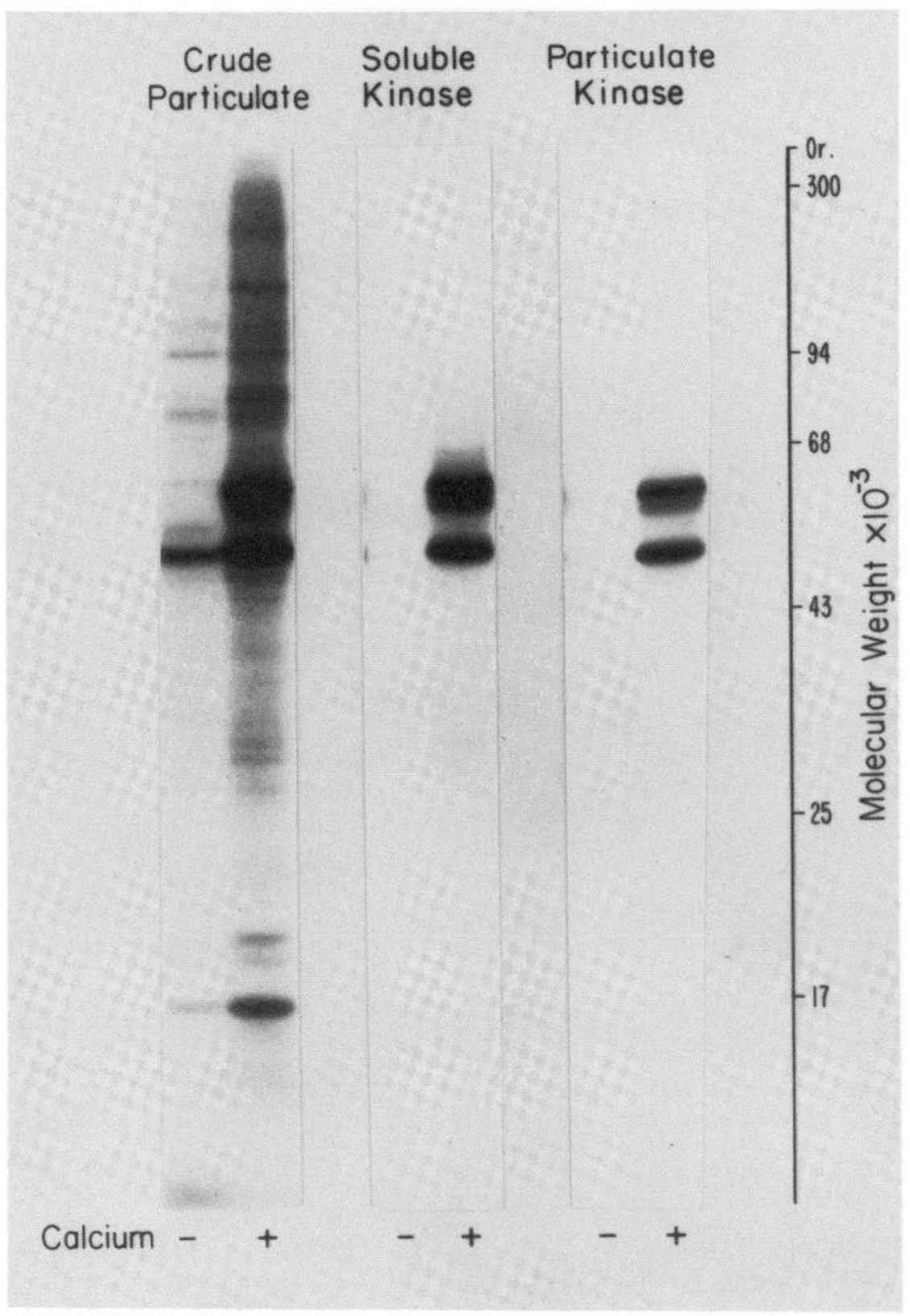

Figure 7. Autoradiogram comparing endogenous calcium/calmodulin-dependent phosphorylation of various kinase preparations by one-dimensional SDS/polyacrylamide gel electrophoresis. Endogenous phosphorylation was carried out for 30 sec in the presence or absence of calcium as indicated. The amounts of protein phosphorylated were: crude particulate fraction, $60 \mu \mathrm{g}$; partially purified soluble kinase, $2.1 \mu \mathrm{g}$; and partially purified particulate kinase, $0.8 \mu \mathrm{g}$.

ent in the crude particulate fraction had similar mobilities upon two-dimensional gel electrophoresis. Two-dimensional electrophoresis of a mixture of the partially purified soluble kinase and the crude particulate fraction showed identical electrophoretic mobilities of these substrates (data not shown). Identical results were also obtained when either the crude synaptosomal membrane fraction or the partially purified particulate kinase preparation was subjected to two-dimensional gel electrophoresis (data not shown). Proteolytic phosphopeptide mapping of the 50-, 58-, and 61-Kd substrates present in crude and partially purified kinase preparations supported the conclusion that phosphorylated proteins of the same molecular weights in the various preparations were indistinguishable (Fig. 9).

Identification of the 50-Kd substrate as the major protein in the partially purified enzyme preparations. The partially purified soluble Synapsin I kinase obtained upon calmodulin-Sepharose affinity chromatography contained one major protein-staining band of $M_{\mathrm{r}} 50 \mathrm{Kd}$ as visualized by SDS/polyacrylamide gel electrophoresis (Fig. 1). This band co-migrated with a radioactive phosphoprotein (Fig. 10). Direct evidence that the stained band and the radioactively labeled band are the same protein was provided by two-dimensional gel electrophoresis (Fig. 11). Similar results were obtained for the 


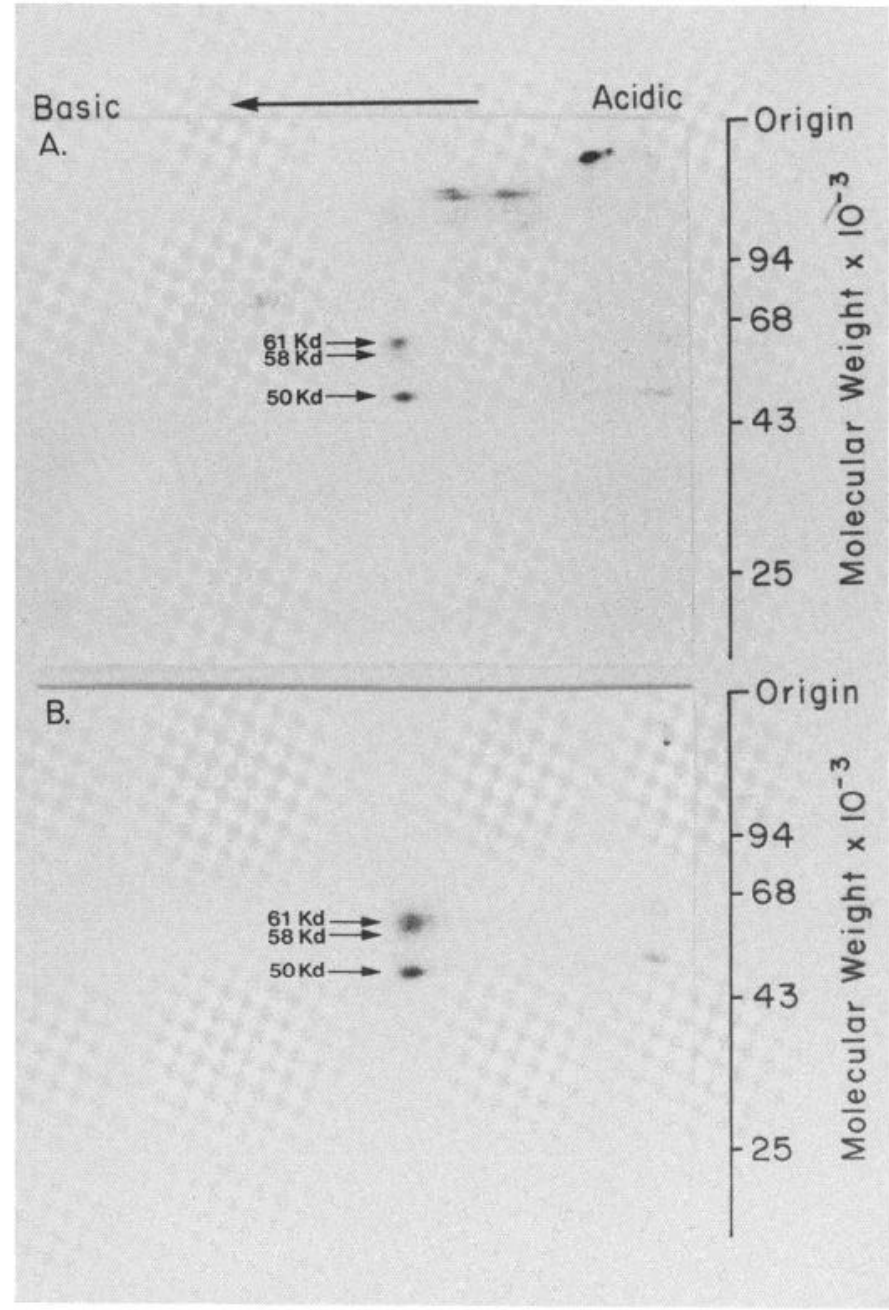

Figure 8. Autoradiogram comparing endogenous calcium/ calmodulin-dependent phosphorylation of crude and purified kinase preparations by two-dimensional gel electrophoresis. Endogenous phosphorylation was carried out for $30 \mathrm{sec}$ in the presence of calcium and the reaction terminated by the addition of an equal volume of urea lysis buffer. The samples were brought to $9.5 \mathrm{M}$ urea and stored at $-20^{\circ} \mathrm{C}$ until subjected to two-dimensional gel electrophoresis and autoradiography. The amounts of protein phosphorylated and subjected to two-dimensional gel electrophoresis were: $A$, crude particulate fraction, $12.5 \mu \mathrm{g} ; B$, partially purified soluble kinase, $1.8 \mu \mathrm{g}$.

partially purified particulate kinase (data not shown). In contrast, the 61- and 58-Kd phosphoproteins did not comigrate with the most abundant proteins in their molecular weight region.

Co-migration of the 50-Kd substrate protein and Synapsin I kinase activity. The observation that the $50-\mathrm{Kd}$ substrate protein was the major protein band in the partially purified enzyme preparations suggested that this protein may be a component of the enzyme. It was not possible to quantitate the amount of the $50-\mathrm{Kd}$ substrate in the early steps of the purification procedure either by protein stain, because of interference from other endogenous bands, or by phosphate incorporation, because of variability apparently due to the presence of endogenous ATPases and/or phosphatases. However, qualitatively, the $50-\mathrm{Kd}$ substrate protein appeared to be distributed between the crude cytosol and particulate fractions in about the same proportion as Synapsin I kinase activity. The $50-\mathrm{Kd}$ band could be clearly visualized by protein stain later in the purification, and it copurified with enzyme activity through the chromatography steps listed in Tables I and II. This observation is illustrated in Figure 1 (arrows), in which it can be seen that the 50-Kd protein was retained on calmodulin-Sepharose in the presence of calcium, as was the Synapsin I kinase activity (Table I), and was eluted with the enzyme by EGTA-containing buffer. Moreover, when the partially purified enzyme was rechromatographed on DEAE-cellulose, as described earlier, the 50 -Kd protein coincided with the peak of enzyme activity (Fig. 12).

\section{Discussion}

Various calcium and calmodulin-dependent protein kinase activities have been reported in brain (Schulman and Greengard, 1978a, b; DeLorenzo et al., 1979; Yamauchi and Fujisawa, 1980; Burke and DeLorenzo, 1981; Grab et al., 1981; Kennedy and Greengard, 1981), as well as in non-neuronal tissues (Cohen et al., 1978; Dabrowska et al., 1978; Waisman et al., 1978; Yagi et al., 1978; Payne and Soderling, 1980; Ahmad et al., 1982). The brain calmodulin-dependent kinases have not been extensively purified, and their characteristics are not yet well defined. Consequently, it is not possible to say whether the various kinase activities observed in brain tissue are due to only a few enzymes with rather broad substrate specificity or to numerous enzymes with relatively narrow substrate specificity.

In the present study, we have partially purified and characterized a calcium/calmodulin-dependent kinase activity from rat brain which phosphorylates a neuronspecific, synaptic vesicle-associated protein designated Synapsin I. This Synapsin I kinase activity was previously shown to be present in both soluble and particulate fractions of rat brain homogenates (Kennedy and Greengard, 1981). The partially purified kinase from the soluble fraction and the partially purified kinase extracted from the particulate fraction exhibited similar characteristics, including $\mathrm{pH}$ dependence, requirement for calcium and calmodulin, affinity for ATP and Synapsin I, substrate specificity, and behavior upon DEAE-cellulose chromatography. The fact that a major portion of the particulate enzyme was solubilized by dilution into a low ionic strength buffer suggests that it is not tightly bound to the membrane. Thus, Synapsin I kinase may exist in a dynamic equilibrium between the soluble and particulate fractions.

Three phosphoproteins previously observed as prominent substrates for a calcium/calmodulin-dependent kinase in a crude particulate preparation from brain (Schulman and Greengard, 1978a, b) were found to be present in both of the partially purified Synapsin I kinase preparations. One of these substrates, a $50-\mathrm{Kd}$ protein, was the major protein band in the partially purified preparations and appeared to co-purify with the kinase activity. These results suggest that the $50-\mathrm{Kd}$ protein 


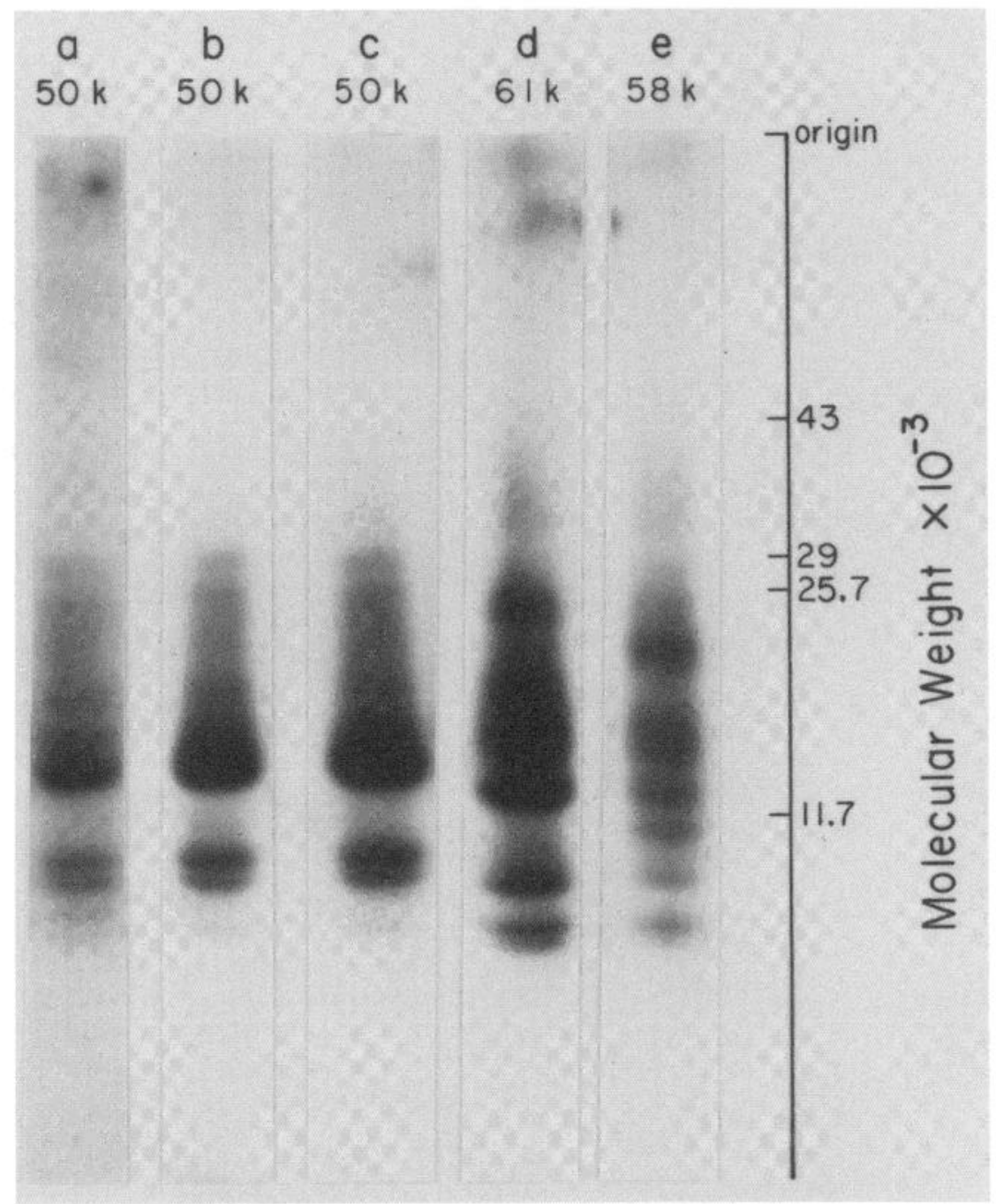

Figure 9. Autoradiogram comparing endogenous calcium/calmodulin-dependent phosphorylation of various kinase preparations by proteolytic phosphopeptide mapping. Endogenous phosphorylation was carried out for 30 sec in the presence of calcium, and the resultant phosphoproteins were subjected to SDS/polyacrylamide gel electrophoresis. The indicated bands were located by autoradiography, cut from the dried gel, and then subjected to limited proteolysis with S. aureus V8 protease in a second SDS/ polyacrylamide gel, followed by autoradiography. $a$, Phosphopeptide map of the 50-Kd protein from the crude synaptosomal membrane fraction. $b$, Phosphopeptide map of the 50-Kd protein from the partially purified soluble kinase. $c$, Phosphopeptide map of the $50-\mathrm{Kd}$ protein from the partially purified particulate kinase. $d$, Phosphopeptide map of the 61-Kd protein from the partially purified soluble kinase. $e$, Phosphopeptide map of the 58-Kd protein from the partially purified soluble kinase. Maps of the $61-\mathrm{Kd}$ and $58-\mathrm{Kd}$ proteins from the crude synaptosomal membrane fraction and from the partially purified particulate kinase were indistinguishable from those of the corresponding proteins present in the soluble kinase (data not shown). Maps of the 61$\mathrm{Kd}, 58-\mathrm{Kd}$, and $50-\mathrm{Kd}$ proteins from the crude particulate fraction (step 3, Table II) were essentially identical to those shown here. The amounts of radioactivity in the bands subjected to proteolysis were: $a, 10,000 \mathrm{cpm} ; b, 27,800 \mathrm{cpm} ; c, 27,700 \mathrm{cpm} ; d$, $48,000 \mathrm{cpm} ; e, 24,000 \mathrm{cpm}$..

may be an autophosphorylatable subunit of the kinase or that it may exist in a complex with the enzyme which is not dissociated under the conditions used in the purification. Although the 61-Kd substrate incorporated at least as much phosphate as the 50 -Kd substrate under most of the conditions used in this study, it and the 58Kd substrate appeared to be present in much lower concentrations based on the intensity of their staining with Coomassie blue (see Fig. 11). Consequently, it was not possible to monitor them by protein staining during the enzyme purification. However, the radiolabeled 58-
$\mathrm{Kd}$ and 61-Kd phosphobands appeared to co-purify with the kinase activity through the centrifugation and chromatography steps (data not shown), suggesting that they, too, may be components of the enzyme complex.

Proteolytic phosphopeptide mapping of the three substrates revealed several peptides common to the $58-\mathrm{Kd}$ and 61-Kd proteins (Fig. 9). Therefore, these two proteins may be related. For example, the $58-\mathrm{Kd}$ protein may have been generated from the $61-\mathrm{Kd}$ protein by proteolysis. In contrast, the phosphopeptide pattern of the 50$\mathrm{Kd}$ protein was quite different from that of the other two 


\section{Protein Stain}

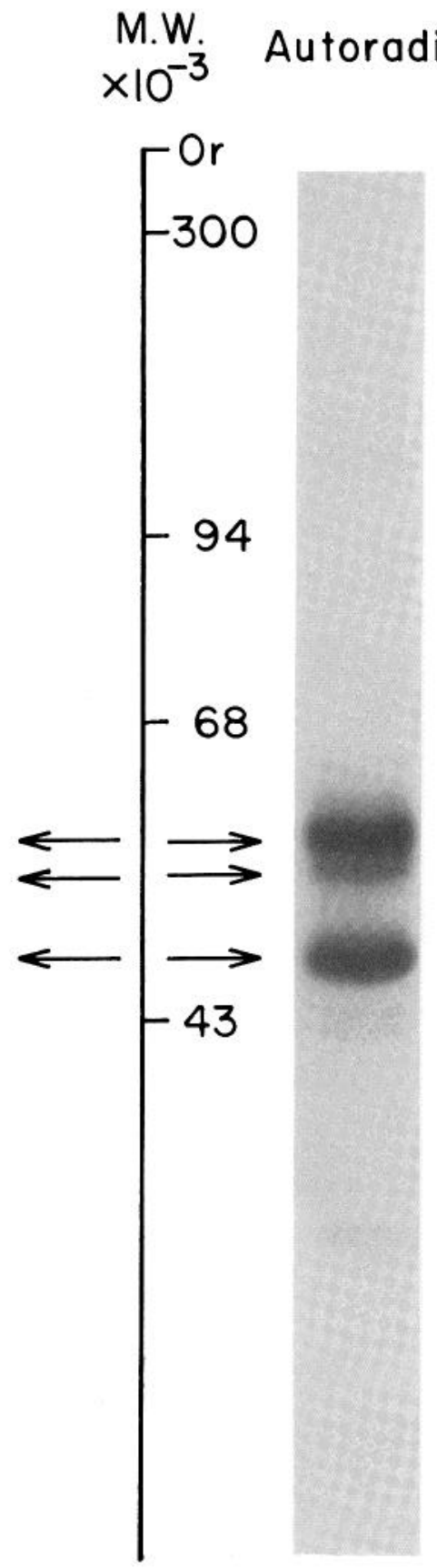

Figure 10. SDS/polyacrylamide gel electrophoresis comparing protein-staining pattern and autoradiogram of endogenously phosphorylated substrates present in the partially purified soluble kinase. Soluble kinase $(2.6 \mu \mathrm{g})$ was phosphorylated for 30 $\mathrm{sec}$ in the presence of calcium. The reaction was terminated by the addition of SDS stop solution. An aliquot containing $1 \mu \mathrm{g}$ of phosphorylated kinase was added to $13 \mu \mathrm{g}$ of soluble kinase, and the mixture was subjected to SDS/polyacrylamide gel electrophoresis. The gel was stained with Coomassie brilliant blue, followed by autoradiography. Arrows point to the 61-, $58-$, and $50-\mathrm{Kd}$ proteins. The kinase preparation was the same as that used for Figure 1. The experimental procedures, including the large amount of protein and the photographic conditions, were designed to permit visualization of the minor proteins present in the preparation. proteins. Therefore, it is unlikely that the $50-\mathrm{Kd}$ substrate was derived from either of the larger proteins. Consistent with this latter interpretation, inclusion of additional protease inhibitors (soybean trypsin inhibitor, leupeptin, and iodoacetamide) during the homogenization did not significantly alter the pattern of phosphorylated proteins in the final enzyme preparations shown in Figure 7 (M. B. Kennedy, unpublished observations).

Burke and DeLorenzo $(1981,1982)$ have reported that endogenous $\alpha$ - and $\beta$-tubulin are phosphorylated in brain homogenates by a calcium/calmodulin-dependent protein kinase. The 50-, 58-, and 61-Kd proteins discussed in this paper were separated from the tubulin dimer on $10 \%$ SDS/polyacrylamide gels (Fig. 1) and have considerably more basic isoelectric points than either $\alpha$ - or $\beta$-tubulin (T. McGuinness, unpublished observations). Moreover, endogenous tubulin is removed from Synapsin I kinase by the DEAE chromatography step (M. B. Kennedy, unpublished observations). Thus, the 50-, 58-, and 61-Kd proteins discussed in this paper seem to be distinct from $\alpha$ - and $\beta$-tubulin.

The glycogen synthase kinase purified by Ahmad et al. (1982) contains two autophosphorylatable subunits of 51 and $53 \mathrm{Kd}$. In this respect, its structure may be similar to the Synapsin I kinase. However, the two enzymes seem to have different substrate specificities. The glycogen synthase kinase phosphorylates phosvitin and casein and does not phosphorylate histone IIa; in contrast, Synapsin I kinase phosphorylates a component of histone IIa (histone $\mathrm{H} 3$ ), phosphorylates casein only poorly, and does not phosphorylate phosvitin (Table III).

The apparent $K_{m}$ of Synapsin I kinase for Synapsin I is about $0.4 \mu \mathrm{M}$, whereas the $K_{m}$ of myosin light chain kinase for the P-light chain is 6 to $18 \mu \mathrm{M}$ (Adelstein and Klee, 1980; Hathaway et al., 1980) and the $K_{m}$ of phosphorylase kinase for phosphorylase b is $33 \mu \mathrm{M}$ (Krebs et al., 1964). Thus the Synapsin I kinase seems to have a much greater affinity for Synapsin I than these other two calmodulin-dependent protein kinases have for their substrates.

It was found previously that the calcium/calmodulindependent Synapsin I kinase activity was much higher in rat brain than in any other rat tissue examined (Kennedy and Greengard, 1981). Synapsin I kinase activity has also been found in nervous tissue of a variety of other vertebrate and invertebrate species. The specific activities $(\mathrm{pmol} / \mathrm{min} / \mathrm{mg})$ in one series of studies were: rat brain, 2200; goldfish brain, 1820; Torpedo californica electroplaque, 1770; Manducta sexta (moth) brain, 917; chicken brain, 464; starfish nerve, 44 (M. B. Kennedy, unpublished observations). Preliminary experiments suggest that Synapsin I kinase may be a relatively abundant brain protein, possibly constituting as much as $0.1 \%$ of the total brain protein (data not shown). This is similar to the concentration of myosin light chain kinase in smooth muscle (Adelstein and Klee, 1980) and of phosphorylase kinase in skeletal muscle (Cohen, 1978). Thus, activation of this kinase may be one of the major biochemical responses of neuronal tissue to increases in calcium concentration. 


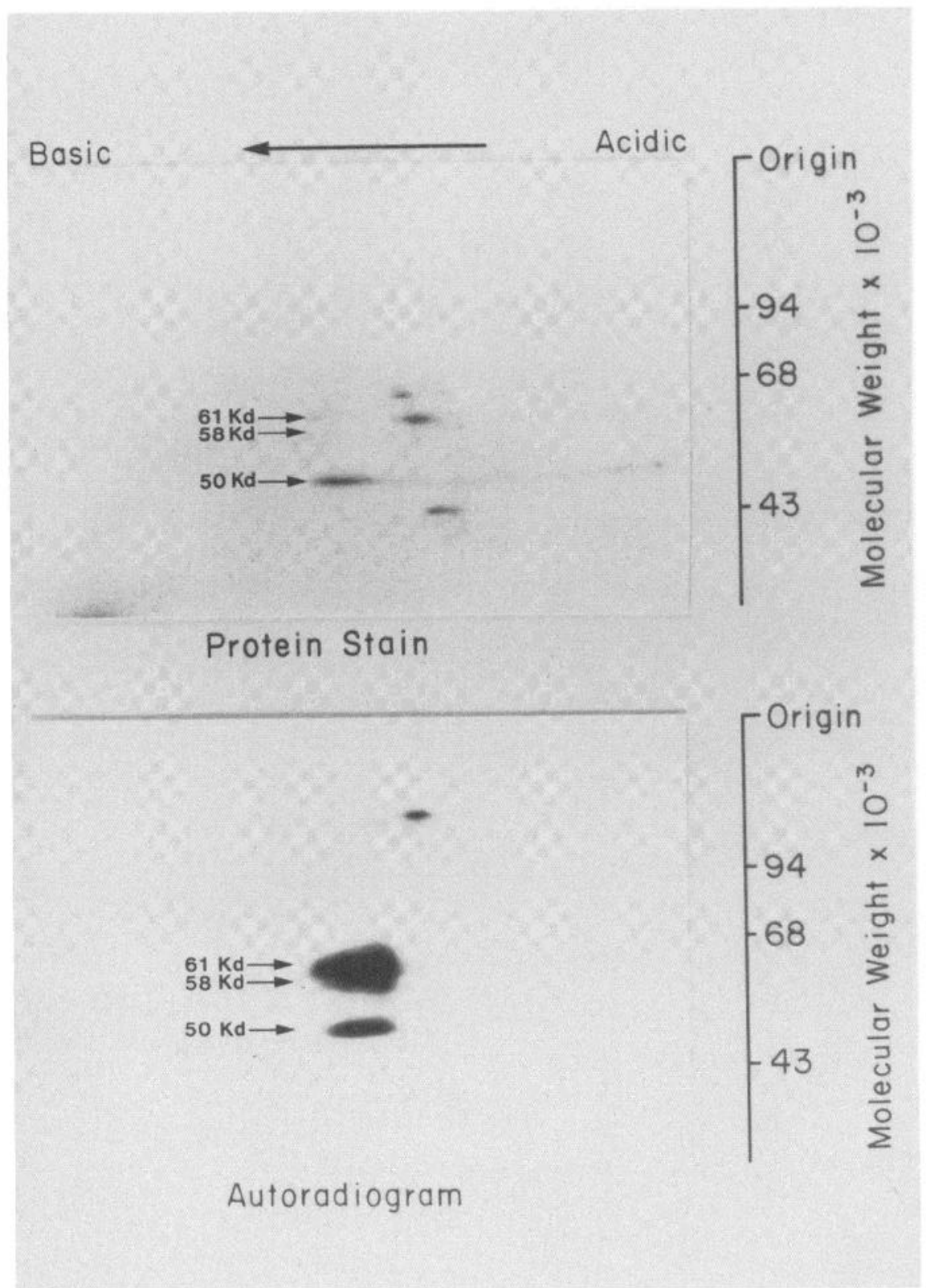

Figure 11. Two-dimensional gel electrophoresis comparing protein-staining pattern and autoradiogram of endogenously phosphorylated substrates present in the partially purified soluble kinase. Soluble kinase ( $3 \mu \mathrm{g})$ was phosphorylated for 30 sec in the presence of calcium, and the reaction was terminated by the addition of $10 \mu \mathrm{l}$ of a solution containing $10 \mathrm{~mm}$ unlabeled ATP and $0.3 \mathrm{~m}$ EDTA. Unphosphorylated partially purified soluble kinase $(27 \mu \mathrm{g})$ was added, and the combined sample was dialyzed against $5 \mathrm{~mm}$ ammonium bicarbonate, lyophilized, resuspended in $60 \mu \mathrm{l}$ of urea lysis buffer, and subjected to two-dimensional gel electrophoresis. The gel was stained with Coomassie brilliant blue, followed by autoradiography. 


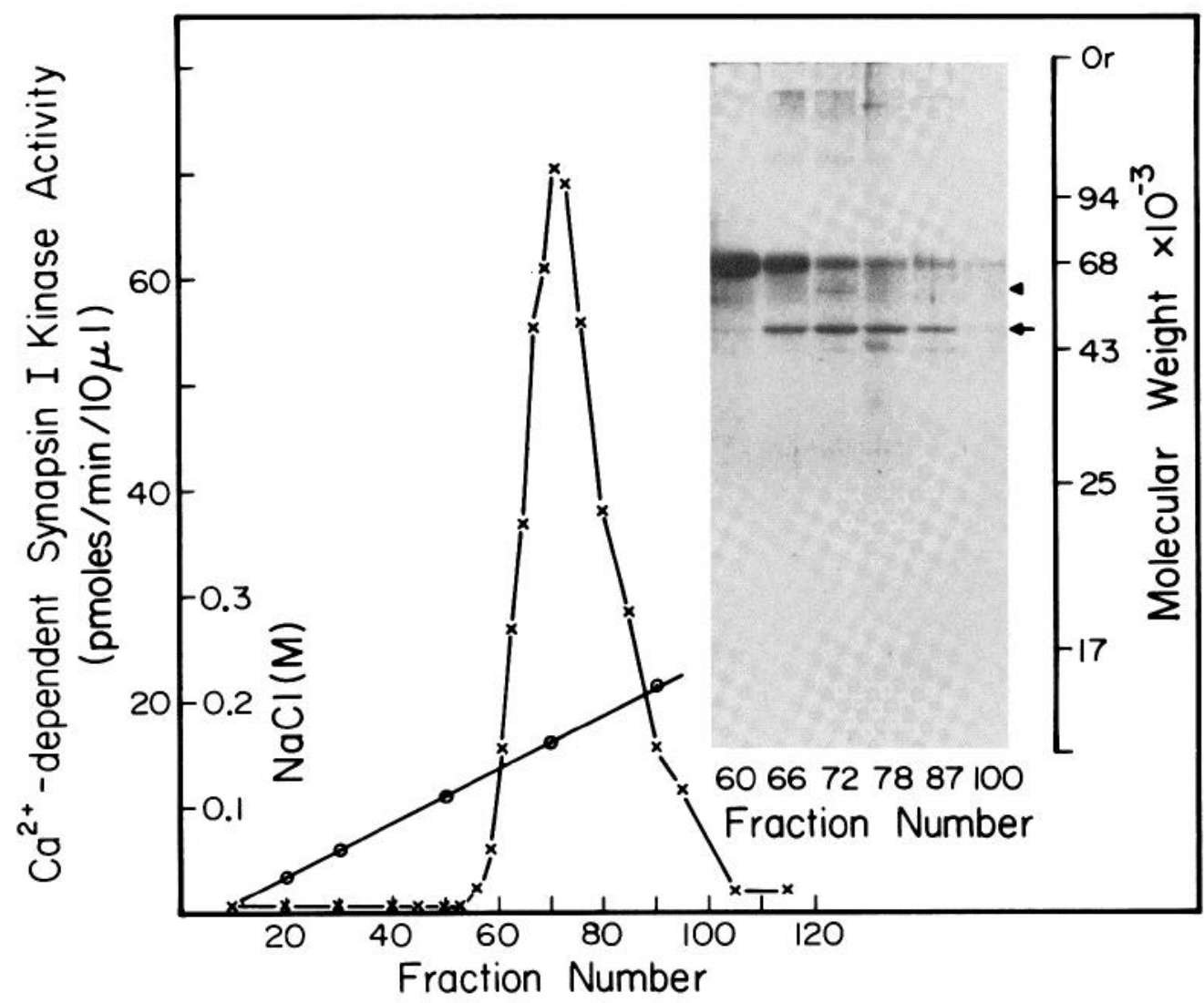

Figure 12. Co-elution of the 50-Kd phosphoprotein with Synapsin I kinase activity during DEAE-cellulose chromatography. Partially purified soluble kinase $(360 \mu \mathrm{g})$ (step 5, Table I) was applied in a volume of $10 \mathrm{ml}$ of buffer A containing bovine serum albumin $(0.03 \mathrm{mg} / \mathrm{ml})$ to a $0.75 \times 6 \mathrm{~cm}$ column of DEAE-cellulose which had been equilibrated with the same buffer. Elution was carried out at a flow rate of $5 \mathrm{ml} / \mathrm{hr}$ using a $60-\mathrm{ml}$ linear gradient of 0 to $0.3 \mathrm{M} \mathrm{NaCl}$ in buffer A. Fractions of $0.5 \mathrm{ml}$ were collected, and enzyme activity was measured. Protein contained in 0.4-ml aliquots of each of the fractions indicated in the inset was precipitated with ice-cold 10\% TCA, then redissolved in SDS "stop solution" of one-third strength. The pH was adjusted to 6.7 , and the proteins were subjected to SDS/polyacrylamide gel electrophoresis on $10 \%$ gels, followed by staining for protein by Coomassie brilliant blue. The arrow indicates the major 50-Kd protein. The arrowhead marks the position of a protein in the 60 $\mathrm{Kd}$ region which can be seen in fraction 72 . The heavily stained band at $68 \mathrm{Kd}$ is BSA. $\times-\times$, Synapsin I kinase activity, $\bigcirc-0$, salt concentration.

\section{References}

Adelstein, R. S., and C. B. Klee (1980) Smooth muscle myosin light chain kinase. In Calcium and Cell Function, W. Y. Cheung, ed., pp. 167-182, Academic Press, Inc., New York.

Ahmad, Z., A. A. DePaoli-Roach, and P. J. Roach (1982) Purification and characterization of a rabbit liver calmodulindependent protein kinase able to phosphorylate glycogen synthase. J. Biol. Chem. 257: 8348-8355.

Axelrod, N. (1978) Phosphoproteins of adenovirus 2. Virology 87: $366-383$.

Burke, B. E., and R. J. DeLorenzo (1981) $\mathrm{Ca}^{2+}$ - and calmodulinstimulated endogenous phosphorylation of neurotubulin. Proc. Natl. Acad. Sci. U. S. A. 78: 991-995.

Burke, B. E., and R. J. DeLorenzo (1982) $\mathrm{Ca}^{2+}$ and calmodulindependent phosphorylation of endogenous synaptic vesicle tubulin by a vesicle-bound calmodulin kinase system. J. Neurochem. 38: 1205-1218.

Cheung, W. Y. (1980) Calmodulin plays a pivotal role in cellular regulation. Science 207: 19-27.

Cleveland, D. W., S. G. Fischer, M. W. Kirschner, and U. K. Laemmli (1977) Peptide mapping by limited proteolysis in sodium dodecyl sulfate and analysis by gel electrophoresis. J. Biol. Chem. 252: 1102-1106.
Cohen, P. (1978) The role of cyclic-AMP-dependent protein kinase in the regulation of glycogen metabolism in mammalian skeletal muscle. Curr. Top. Cell. Regul. 14: 117-196.

Cohen, P., A. Burchell, J. G. Foulkes, P. T. W. Cohen, T. C. Vanaman, and A. C. Nairn (1978) Identification of the $\mathrm{Ca}^{2+}$. dependent modulator protein as the fourth subunit of rabbit skeletal muscle phosphorylase kinase. FEBS Lett. 92: 287293.

Cold Spring Harbor Laboratories (1972) The Mechanism of Muscle Contraction. Cold Spring Harbor Symp. Quant. Biol., Vol. 37.

Dabrowska, R., J. M. F. Sherry, P. K. Aromatorio, and D. J. Hartshorne (1978) Modulator protein as a component of the myosin light chain kinase from chicken gizzard. Biochemistry 17: 253-258.

DeLorenzo, R. J., S. D. Freedman, W. B. Yohe, and S. C. Maurer (1979) Stimulation of $\mathrm{Ca}^{2+}$-dependent neurotransmitter release and presynaptic nerve terminal protein phosphorylation by calmodulin and a calmodulin-like protein isolated from synaptic vesicles. Proc. Natl. Acad. Sci. U. S. A. 76: 1838-1842.

Eadie, G. S. (1942) The inhibition of cholinesterase by physostigmine and prostigmine. J. Biol. Chem. 146: 85-93.

Glynn, I. M., and J. B. Chappell (1964) A simple method for 
the preparation of ${ }^{32}$-labelled adenosine triphosphate of high specific activity. Biochem. J. 90: 147-149.

Grab, D. J., R. K. Carlin, and P. Siekevitz (1981) Function of calmodulin in post-synaptic densities. II. Presence of a calmodulin-activatable protein kinase activity. J. Cell Biol. 89: 440-448.

Gray, E. G., and V. P. Whittaker (1962) The isolation of nerve endings from brain: An electron microscopic study of cell fragments derived by homogenization and centrifugation. J. Anat. 96: 79-88.

Hathaway, D. R., C. R. Eaton, and R. S. Adelstein (1980) Regulation of human platelet myosin kinase by calciumcalmodulin and cyclic AMP. In The Regulation of Coagulation, K. G. Mann and F. B. Taylor, eds., pp. 271-276, Elsevier, New York.

Hofstee, B. H. J. (1959) Non-inverted versus inverted plots in enzyme kinetics. Nature 184: 1296-1298.

Huttner, W. B., and P. Greengard (1979) Multiple phosphorylation sites in protein I and their differential regulation by cyclic AMP and calcium. Proc. Natl. Acad. Sci. U. S. A. 76: 5402-5406.

Huttner, W. B., L. J. DeGennaro, and P. Greengard (1981) Differential phosphorylation of multiple sites in purified protein I by cyclic AMP-dependent and calcium-dependent protein kinases. J. Biol. Chem. 256: 1482-1488.

Kelly, R. B., J. W. Deutsch, S. S. Carlson, and J. A. Wagner (1979) Biochemistry of neurotransmitter release. Annu. Rev. Neurosci. 2: 399-446.

Kennedy, M. B., and P. Greengard (1981) Two calcium/calmodulin-dependent protein kinases, which are highly concentrated in brain, phosphorylate protein I at distinct sites. Proc. Natl. Açad. Sci. U. S. A. 78: 1293-1297.

Krebs, E. G., D. S. Love, G. E. Bratvold, K. A. Trayser, W. L. Meyer, and E. H. Fischer (1964) Purification and properties of rabbit skeletal muscle phosphorylase b kinase. Biochemistry 3: 1022-1033.

Kretsinger, R. H. (1979) The informational role of calcium in the cytosol. Adv. Cyclic Nucleotide Res. 11: 1-26.

Lowry, O. H., N. J. Rosebrough, A. L. Farr, and R. J. Randall (1951) Protein measurement with the Folin phenol reagent. J. Biol. Chem. 193: 265-275.

March, S. C., I. Parikh, and P. Cuatrecasas (1974) A simplified method for cyanogen-bromide activation of agarose for affinity chromatography. Anal. Biochem. 60: 149-152.

O'Farrell, P. Z., H. M. Goodman, and P. H. O'Farrell (1977)
High resolution two-dimensional electrophoresis of basic as well as acidic proteins. Cell 12: 1133-1142.

Payne, M. E., and T. R. Soderling (1980) Calmodulin-dependent glycogen synthase kinase. J. Biol. Chem. 255: 8054-8056.

Portzehl, H., P. C. Caldwell, and J. C. Ruegg (1964) The dependence of contraction and relaxation of muscle fibres from the crab Maia squinado on the internal concentration of free calcium ions. Biochim. Biophys. Acta 79: 581-591.

Schulman, H., and P. Greengard (1978a) Stimulation of brain membrane protein phosphorylation by calcium and an endogenous heat-stable protein. Nature 271: 478-479.

Schulman, H., and P. Greengard (1978b) $\mathrm{Ca}^{2+}$-dependent protein phosphorylation system in membranes from various tissues, and its activation by "calcium-dependent regulator." Proc. Natl. Acad. Sci. U. S. A. 75: 5432-5436.

Shelanski, M. L., F. Gaskin, and C. R. Cantor (1973) Microtubule assembly in the absence of added nucleotides. Proc. Natl. Acad. Sci. U. S. A. 70: 765-768.

Ueda, T., and P. Greengard (1977) Adenosine 3':5'-monophosphate-regulated phosphoprotein system of neuronal membranes. I. Solubilization, purification, and some properties of an endogenous phosphoprotein. J. Biol. Chem. 252: 51555163 .

Ueda, T., P. Greengard, K. Berzins, R. S. Cohen, F. Blomberg, D. J. Grab, and P. Siekevitz (1979) Subcellular distribution in cerebral cortex of two proteins phosphorylated by a cAMPdependent protein kinase. J. Cell Biol. 83: 308-319.

Waisman, D. M., T. J. Singh, and J. H. Wang (1978) The modulator-dependent protein kinase. J. Biol. Chem. 253: 3387-3390.

Walicke, P. A., and P. H. Patterson (1981) On the role of $\mathrm{Ca}^{2+}$ in the transmitter choice made by cultured sympathetic neurons. J. Neurosci. 1: 343-350.

Watterson, D. M., W. G. Harrelson, P. M. Keller, Jr., F. Sharief, and T. C. Vanaman (1976) Structural similarities between the $\mathrm{Ca}^{2+}$-dependent regulatory proteins of $3^{\prime}: 5^{\prime}$-cyclic nucleotide phosphodiesterase and actomyosin ATPase. J. Biol. Chem. 251: 4501-4513.

Yagi, K., M. Yazawa, M. Kakiuchi, M. Ohshima, and K. Uenishi (1978) Identification of an activator protein for myosin light chain kinase as the $\mathrm{Ca}^{2+}$-dependent modulator protein. J. Biol. Chem. 253: 1338-1340.

Yamauchi, T., and H. Fujisawa (1980) Evidence for three distinct forms of calmodulin-dependent protein kinases from rat brain. FEBS Lett. 116: 141-144. 